\title{
Roles of Insulin and Glucose in the Regulation of Plasma FFA in the Duck
}

\author{
I. In the Absence of Pancreatic Glucagon \\ R. Gross and P. Mialhe \\ Laboratoire de Physiologie Générale, Université Louis Pasteur, Strasbourg, France
}

\begin{abstract}
Summary. The present study was undertaken to determine how free fatty acid (FFA) release by adipose tissue can occur in the absence of pancreatic glucagon, the most potent lipolytic hormone in the duck. Two possible explanations have successively been investigated. Replacement therapy experiments showed that glucose uptake was implicated in the phenomenon; indeed, when pre-operative insulin and glucose levels were restored after total pancreatectomy, plasma FFA progressively fell to a level significantly lower than the pre-operative value. The same effect was observed when the ducks were kept in a continuous state of hyperglycaemia, whereas "normal" levels of insulin or glucose alone were shown to be ineffective. On the other hand a compensatory mechanism for the lack of glucagon, by other lipolytic agents [with the intestine or the anterior pituitary as possible sources] has been excluded by associating the removal of these two organs with pancreatectomy. These experiments suggest that the lack of pancreatic glucagon induced by total pancreatectomy is essentially masked by a failure in glucose uptake due to the operation.
\end{abstract}

Key words: Duck, adipose tissue, FFA release, glucagon, insulin, glucose uptake.

Totally pancreatectomised ducks become hypoglycaemic within $3 \mathrm{~h}$ of operation [1], because of the total elimination of pancreatic glucagon [2]. Glucagon is a very potent lipolytic agent in the duck both in vivo $[3,4]$ and in vitro $[3,5]$ but the drop in plasma FFA observed after pancreatectomy is surprisingly delayed: a significant difference from pre-operative values was only observed after one day [3]. Two possible causes for such a delay were investigated:
1. Compensation for pancreatic glucagon by other lipolytic agents, the anterior pituitary and the intestine being possible sources $[3,6,7,8]$ (APP being secreted in the fed animal [9], and somatostatin having been shown to have an indirect effect in mammals [10]).

2. The unexpectedly high level of plasma FFA as a result of the new metabolic and hormonal status due to the operation per se. Indeed, total pancreatectomy is also followed by a complete absence of insulin, and, as already mentioned, deep hypoglycaemia.

These two possibilities have been successively tested:

1. By comparing pancreatectomy to pancreatectomy plus hypophysectomy and pancreatectomy plus partial evisceration;

2. By restoring to normal the levels of several of the plasma components other than glucagon which had been affected by removal of the pancreas: glucose, insulin and finally both variables.

\section{Material and Methods}

\section{Animals}

Adult male Peking ducks, weighing between 1.8 and $2.8 \mathrm{~kg}$ were used. The animals were kept outdoors, then transferred indoors into individual cages and deprived of food 16 hours before the experiments. Hypophysectomized animals were kept indoors 8 weeks prior to the experiments and maintained on the same normal fowl diet ("BPN Grands Moulins de Paris", Nancy, France).

\section{Operations}

All operations were performed under local anaesthesia (Xylocaïne 1\%, Bellon S. A., Neuilly, France). 
1. Total Pancreatectomy: The pancreas was removed from normal or hypophysectomized animals according to Mialhe's technique [2].

\section{Total Pancreatectomy Plus Partial Evisceration:} The animals were first totally pancreatectomised and then partially eviscerated [11]. The duodenum which is devoid of GLI activity in the duck [12] was left in place.

3. Hypophysectomy: The anterior pituitary was removed according to Martin's technique [13] modified by Benoît [14]. The operation was checked by testicular regression and plasma glucose decrease.

\section{Treatment and Blood Sampling}

Blood samples were collected into heparinized syringes $(50 \mathrm{U} / \mathrm{ml}$ in $\mathrm{NaCl} 9 \mathrm{~g} / \mathrm{l} ; 1 \%$ of the plasma volume) centrifuged at $5^{\circ} \mathrm{C}$ and the plasma samples frozen until use. The ducks were attached on their backs to a board during the whole experiment, and those subjected to a spaced-out treatment were returned to their cages between sampling. Continuous treatment was given to ducks left permanently out of their cages. Indwelling polyethylene catheters were inserted into a wing vein just before the end of the operation, allowing immediate treatment. Insulin $(20 \mathrm{mU} / \mathrm{kg} / \mathrm{h})$ and saline $(\mathrm{NaCl} 9 \mathrm{~g} / \mathrm{l})$ were infused at a constant rate of $0.1 \mathrm{ml} / \mathrm{min}$. Thirty per cent glucose in saline was infused at a rate depending on the level of the glycaemia desired; this rate was corrected with an $11 \mathrm{~min}$ latency. The details of the treatments of each group are given in the results section.

\section{Plasma Determinations}

1. Plasma Glucose: The measurements were made according to Hoffman's method [15] with a Technicon autoanalyser.

2. Plasma FFA: The spectrophotocolorimetric method of Laurell and Tibbling [16] was used.

3. Plasma Immunoreactive Insulin (IRI): It was determined by a radioimmunoassay using separation of free from bound radioactive insulin by dextrancoated charcoal [6] and Novo beef insulin as a standard, we therefore give our IRI plasma concentrations as $\mu$ Ueq of beef insulin. Pancreatectomised animals were treated with pig insulin. It must be noted that duck and pig insulin, when read on a beef standard curve, are slightly under and over estimated respectively [17]. The sensivity of the assay is $2.5 \mu \mathrm{U} / \mathrm{ml}$ and the SEM ranges between 0.2 and 0.3 for plasma concentrations between 0 and $10 \mu \mathrm{Ueq} / \mathrm{ml}$.

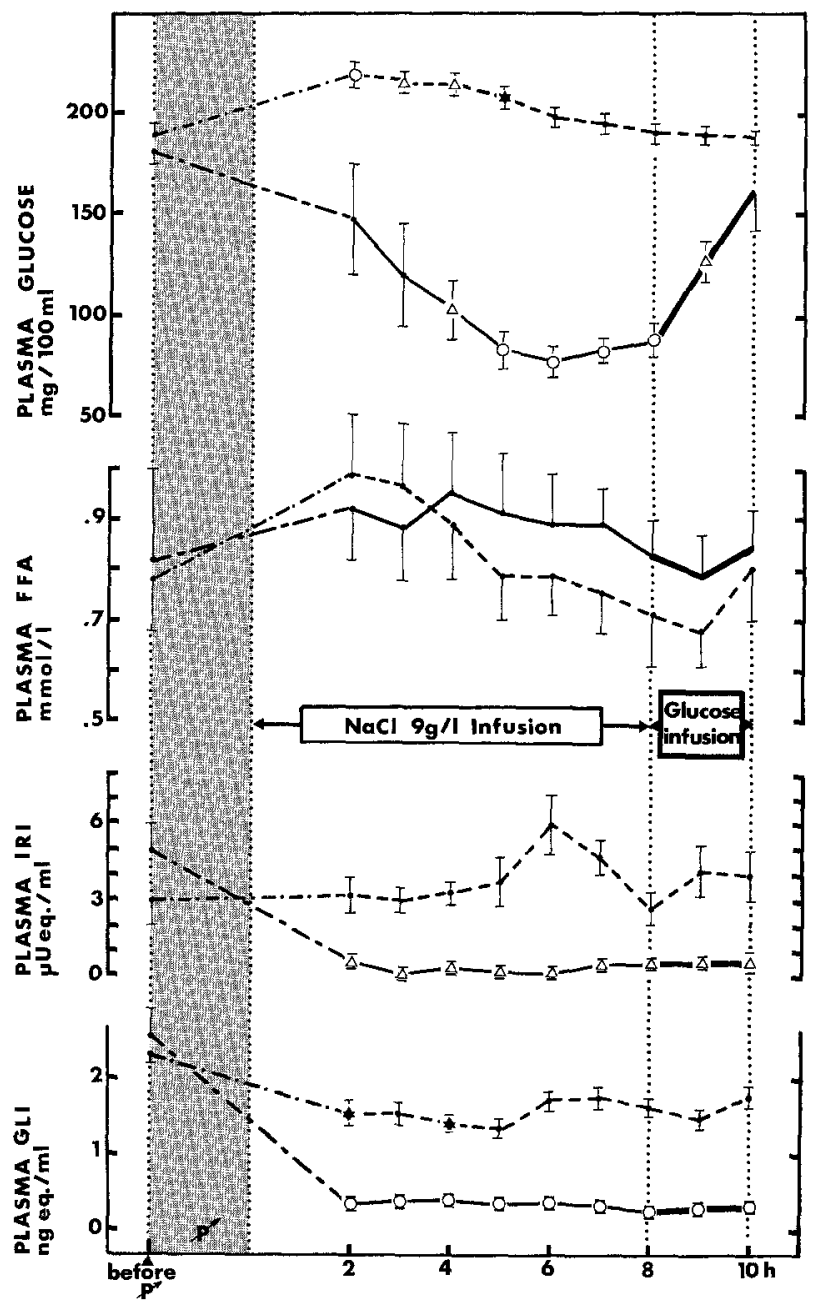

Fig. 1. Effect of an infusion of saline $(9 \mathrm{~g} / 1,6 \mathrm{ml} / \mathrm{h})$ into 9 totally pancreatectomised ducks and 11 sham-operated animals. Vertical bars represent \pm SEM. $\star=p<0.05, \Delta=p<0.01, O=p<$ 0.001 . Pancreatectomised animals are shown by full lines, and controls by dotted lines. pr means pancreatectomy

4. Plasma Glucagon-Like-Immunoreactivity (GLI): Plasma GLI was measured by radioimmunoassay with a nonspecific antibody; trasylol was shown to be useless for preventing degradation of glucagon in duck plasma [18]. The results, read from a pig standard curve are therefore given as ng eq of pig glucagon and expressed as total circulating GLI except in totally pancreatectomized ducks in which the plasma GLI was of intestinal origin. The sensivity of the assay is $0.1 \mathrm{ng} / \mathrm{ml}$ and the SEM ranges between 0.009 and 0.13 for plasma concentrations between 0 and $2 \mathrm{ng} / \mathrm{ml}$.

\section{Statistical Methods}

Student's $t$ test for paired values was used for the comparison of the means which are represented \pm 
SEM. All the values are compared to those obtained at zero time (pre-operative values).

\section{Results}

1. The Effect of Pancreatectomy: In a group of 13 animals, plasma FFA were measured during the first ten post-operative hours: 2 hours after pancreatectomy the plasma GLI significantly dropped to a value corresponding to the gut GLI level. Plasma FFA remained unchanged for 10 hours. The animals were hypoglycaemic and plasma IRI was no longer detectable.

We had to test the eventual effect of immobilization and infusion on plasma FFA and glucose levels under these conditions (Fig. 1); results similar to those of the preceding groups were obtained. A group (Fig. 1) of 11 sham-operated animals were used as controls. Such animals are hyperglycaemic during the first five postoperative hours and show a significant drop of plasma GLI at 2 and $4 \mathrm{~h}$.

2. Effect of Glucose $(0.18$ to $0.45 \mathrm{~g} / \mathrm{kg} / \mathrm{h})$ Alone (Fig. 2): A fourth experimental group of 9 ducks was infused with saline $(0.1 \mathrm{ml} / \mathrm{min})$ and glucose $(0.18$ to $0.45 \mathrm{~g} / \mathrm{kg} / \mathrm{h}$ ), to maintain plasma glucose in the normal range. No differences from the preceding group were noted, except for a significant elevation in plasma FFA from 8 to $10 \mathrm{~h}$.

\section{Effect of Insulin $(20 \mathrm{mU} / \mathrm{kg} / \mathrm{h}, 0.1 \mathrm{ml} / \mathrm{min})$ and} Glucose at Low Concentrations $(0.45$ to $0.9 \mathrm{~g} / \mathrm{kg} / \mathrm{h})$ (Fig: 2): Thirteen ducks were infused with pig insulin $(20 \mathrm{mU} / \mathrm{kg} / \mathrm{h})$ and glucose $(0.45$ to $0.9 \mathrm{~g} / \mathrm{kg} / \mathrm{h})$ in sufficient amounts to avoid hypoglycaemic convulsions. The plasma insulin level $(8.5 \pm 0.8$ to $5.4 \pm 1.0$ $\mu \mathrm{Ueq} / \mathrm{ml}$ ) during the 8 hours infusion was significantly lower than the pre-operative value. The evolution of plasma glucose and GLI was similar to that observed in the preceding groups and once more no significant change in plasma FFA was noticed.

Fig. 2. Panel $2 A$ : Effect of an infusion of saline $(9 \mathrm{~g} / 1,6 \mathrm{ml} / \mathrm{h})$ and glucose at a rate $(0.18$ to $0.45 \mathrm{~g} / \mathrm{kg} / \mathrm{h})$ chosen to keep plasma glucose in the normal range, on plasma glucose, FFA, IRI and GLI levels into 9 totally pancreatectomised ducks. Same symbols as in Figure 1. Panel $2 B$ : Effect on plasma glucose, FFA, IRI and GLI levels of an infusion of insulin $(20 \mathrm{mU} / \mathrm{kg} / \mathrm{h})$ and glucose at a rate of 0.45 to $0.9 \mathrm{~g} / \mathrm{kg} / \mathrm{h}$ (to avoid hypoglycaemic convulsions) into 13 pancreatectomised ducks. Same symbols as in Figure 1. Panel $2 \mathrm{C}$ : Effect of an infusion of insulin $(20 \mathrm{mU} / \mathrm{kg} / \mathrm{h})$ and glucose $(0.45$ to $1.8 \mathrm{~g} / \mathrm{kg} / \mathrm{h}$ ) maintaining plasma glucose in the normal range. Plasma glucose, FFA, IRI and GLI levels were measured in 11 pancreatectomised ducks, Same symbols as in Figure 1
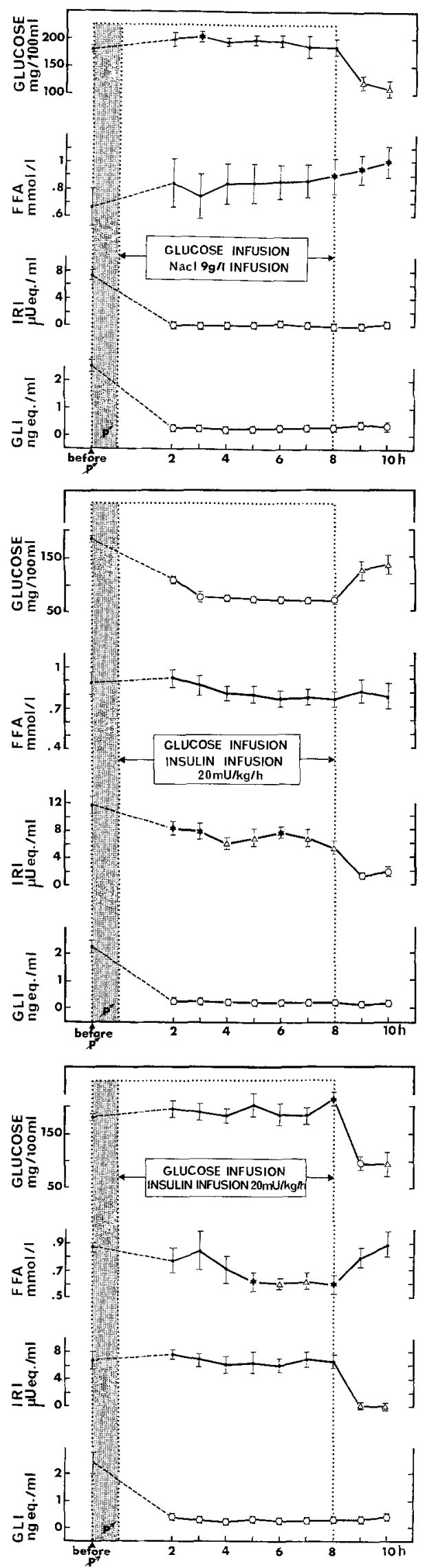

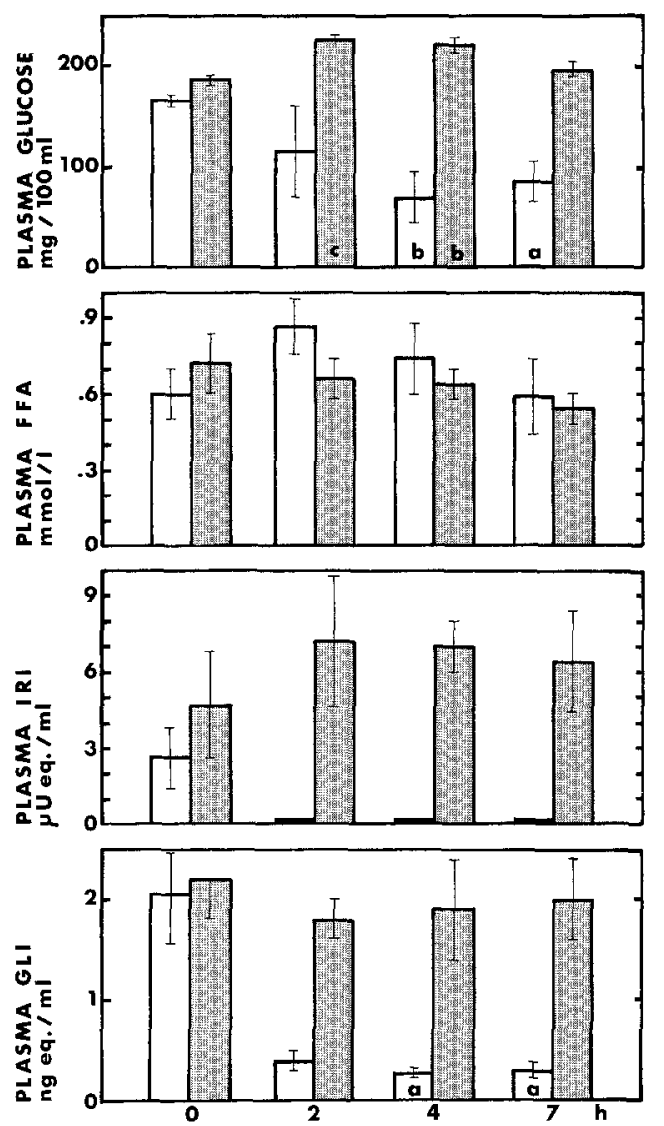

Fig. 3. Effect of pancreatectomy in 7 hypophysectomised ducks, on plasma glucose, FFA, IRI and GLI levels. Sham operated animals are figured in shaded areas-vertical bars represent \pm SEM. $a=p$ $<0.05, b=p<0.01, c=p<0.001$. These levels of significance are given versus 0 time of the same group

4. Effect of Insulin $(20 \mathrm{mU} / \mathrm{kg} / \mathrm{h})$ Associated with Glucose $(0.45$ to $1.8 \mathrm{~g} / \mathrm{kg} / \mathrm{h})$ (Fig. 2): Eleven ducks were treated with the same dose of insulin, but glucose was given in order to keep the plasma glucose in the normal range. The same level of IRI as in the preceding experiment was reached. A significant drop in plasma FFA occurred 5 hours after total pancreatectomy. At 7 hours, the difference from the preoperative value $(0.870 \pm 0.027 \mathrm{mmol} / \mathrm{l})$ was highly significant $(0.614 \pm 0.061 \mathrm{mmol} / \mathrm{l})$.

5. Effect of Glucose Injections $(0.45$ to $0.75 \mathrm{~g} / \mathrm{kg} / \mathrm{h})$ : Seven ducks received IV and IP injections of glucose to maintain them in a hyperglycaemic state. These animals were only immobilized during blood sampling and glucose injections. They showed, in the absence of pancreatic glucagon and insulin, a significant drop in plasma FFA from $0.956 \pm 0.094$ to $0.530 \pm$ $0.104 \mathrm{mmol} / \mathrm{l}, 4$ hours after the end of the operation.

6. Hypophysectomised-Pancreatectomised Animals (Fig. 3): Seven ducks hypophysectomised one month previously, were pancreatectomised (time 0 of the experiment). Plasma IRI was undetectable and the GLI level reduced to that of gut GLI level ranging between 0.41 and $0.28 \mathrm{ngEq} / \mathrm{ml}$. In these animals, very frequent IV glucose injections were needed to avoid hypoglycaemic convulsions. No significant change in plasma FFA level during the seven hours following pancreatectomy was noted. A group of 7 sham-operated animals is represented in the figure by shaded areas. Such animals were hyperglycaemic during the first four post-operative hours.

7. Partially Eviscerated-Totally Pancreatectomised Animals: These two operations were performed in 5 ducks. They became hypoglycaemic and their plasma IRI was undetectable. Plasma FFA did not change significantly.

\section{Discussion}

1. The Effect of Pancreatectomy on Plasma FFA Level: In most mammals, pancreatectomy provokes an important rise in plasma FFA, as, for example, in the dog [19]. This is in accordance with the important antilipolytic effect of insulin in those species [20]. In birds, the situation is somewhat different. Insulin is not antilipolytic in vivo [3,21,22,23] nor in vitro [3]. In addition, glucagon is a very strong lipolytic factor $[3,21,22]$. Fifteen minutes after a single IV injection of $2 \mu \mathrm{g}$ glucagon $/ \mathrm{kg}$, plasma FFA are doubled, while adipose tissue of fed or fasted ducks responds in vitro to very low concentrations of the hormone [8], as low as $50 \mathrm{pg} / \mathrm{ml}$. We have therefore tried to explain why total pancreatectomy is followed by such a delayed drop in plasma FFA [3]. Our results in totally pancreatectomised animals show that the simultaneous drop in plasma insulin and glucose leading to intracellular glucose shortage could be responsible for the maintenance of the plasma FFA level. When such a drop is prevented, a significant fall in plasma FFA can be observed 5 hours after the end of the operation and the beginning of the treatment; that is probably due to glucagon lack. Insulin or glucose when given alone in order to keep the appropriate concentration in the normal range are ineffective. Continuous hyperglycaemia however, has the same, and an even earlier effect. These results suggest that a failure in glucose uptake into the tissues which can use FFA is responsible for the maintenance of the plasma FFA level after total pancreatectomy.

This failure in glucose uptake is probably not the only factor involved since, when it is corrected, the fall in plasma FFA level only occurs after five hours, a rather long delay. Another factor in addition to 
glucagon must be involved in the regulation of lipolysis in the duck, since its disappearance from the plasma is very rapid. The adrenal gland does not seem to be implicated since the fall of plasma FFA is not more rapid in hypophysectomised ducks. Furthermore, in pancreatectomised infused ducks the increase of plasma FFA at the end of the infusion is rapid.

The plasma FFA level depends on two factors: their release by the adipose tissue, and their removal by other tissues - which seems essentially related to their plasma concentration $[24,25]$. The probable shortage of intracellular glucose following total pancreatectomy should lead to increased uptake of FFA and/or ketone bodies. As far as FFA are concerned, this seems not to be the case; their plasma level remains stable, while the liver total fatty acid content is unchanged [3]. The plasma ketone body level, which has been shown to be independent of plasma insulin and glucagon concentration [26] drops rapidly after pancreatectomy and does not seem to be involved in the changes in FFA.

We therefore tentatively suggest that an abnormality of FFA release is of major importance in the unexpected high level of FFA observed after total pancreatectomy. The rate of release by adipose tissue is determined by the balance between triglyceride breakdown and reesterification of FFA. In pancreatectomised animals, the absence of glucagon, although probably resulting in a decrease in triglyceride breakdown, produces no alteration in the plasma FFA level for a long period ( 24 hours). Glucagon [27] has been shown to stimulate in vitro both triglycerides breakdown and reesterification, the effect on breakdown being more important. So the lack of glucagon should result in a drop of plasma FFA; as this is not the case, an additional important decrease in the reesterification must occur. In the insulin plus glucose treated animals normal reesterification of FFA is probably maintained by the supply of $\alpha$ glycerophosphate. Under these conditions, we can observe a suppression of the glucagon-stimulated effect, i. e. a drop in plasma FFA. Our in vivo results are similar to those obtained in vitro on rat adipose tissue by Weinges [28] who showed that FFA release can be inhibited both by high concentrations of glucose in the absence of added insulin, or by addition of insulin at normal glucose concentrations.

Another in vivo situation where an improvement of glucose uptake induces an abnormality in FFA release has been observed in rats. After stimulation of lipolysis in normal animals with ACTH, 85 per cent of the FFA formed are released compared with only 20 per cent in adrenalectomised rats; this is probably a consequence of the absence of circulating glucocorticoids, leading to a higher uptake of glucose for reesterification [29].

2. Role of Other Lipolytic Hormones: Both hypophysectomy [3] and partial evisceration [7] induce a drop in plasma FFA. When combined with pancreatectomy, they are no longer effective; once again the effects of the absence of insulin and hypoglycaemia induced by pancreatectomy are important. The experiments confirm and emphasize the preceding results obtained in totally pancreatectomised animals.

We may conclude that glucose uptake is important in the regulation of plasma FFA level in the duck. Insulin generally thought to be devoid of any regulatory role in the adipose tissue of birds has been shown to interplay in lipolysis in the absence of pancreatic glucagon. This role is important since it is partly responsible for the high plasma FFA level in the absence of the most potent lipolytic hormone in the duck. We suggest that insulin and glucose act at the level of the reesterification of FFA in liver or adipose tissue.

Acknowledgements. The authors wish to thank Miss M. Horrenberger, Mrs. M. Roth and Mrs. G. Sommermeyer for their skilled technical assistance and Miss M. Porcherot for the realisation of the manuscript.

\section{References}

1. Mialhe, P.: Hypoglycémie et diminution de la tolérance au glucose chez le canard après pancréatectomie totale. C. R. Acad. Sci. [D] (Paris) 241, 1500-1503 (1955)

2. Mialhe, P.: Glucagon, insuline et régulation endocrine de la glycémie chez le canard. Acta Endocrinol. [Suppl.] (Kbh.) 36 1-134 (1958)

3. Desbals, P.: Effets de la pancréatectomie el de l'hypophysectomie sur la circulation des lipides chez le canard. Thèse Univ. Toulouse (1972)

4. Grande, F.: Effect of glucagon on plasma free fatty acids and blood sugar in birds. Proc. Soc. Exp. Biol. Med. 128, 532-536 (1968)

5. Krug, E.: Régulation de la lipolyse chez le canard: importance des glucagons pancréatiques, de l'entéroglucagon et des facteurs intestinaux. Thèse Univ. Strasbourg (1976)

6. Foltzer, C., Mialhe, P.: Pituitary and adrenal control of pancreatic endocrine function in the duck. II. Plasma free fatty acids, aminoacids and replacement therapy with growth hormone and corticosterone. Diab. Met. 2, 101-105 (1976)

7. Gross, R., Mialhe, P.: Free fatty acid-glucagon feed-back mechanism. Diabetologia 10, 277-283 (1974).

8. Krug, E., Mialhe, P.: The contribution of the pancreas and the intestine to the regulation of lipolysis in birds. Horm. Metab. Res. 7, 305-309 (1975)

9. Hazelwood, R.L.: Three avian pancreatic hormones. In: T. A. I. Grillo, L. Leibson, A. Epple (Ed.): The Evolution of Pancreatic Islets. Proc. Symp. Leningrad, pp. 321-334. Oxford: Pergamon Press 1975 
10. Christensen, S. E., Hansen, AA. P., Iversen, J., Lundbaek, K., Orskov, H. and Seyer-Hansen, K.: Somatostatin as a tool in studies of basal carbohydrate and lipid metabolism in man: Modifications of glucagon and insulin release. Scand. J. Clin. Lab. Invest. 34, 321-325 (1974)

11. Krug, E., Biehler, O., Mialhe, P.: Molecular weight of gut and pancreatic circulating glucagons in the duck. Horm. Metab. Res. 3, 258-261 (1971)

12. Krug, E., Mialhe, P.: Pancreatic and intestinal glucagon in the duck. Horm. Metab. Res. 3, 24-27 (1971)

13. Martins, Th.: Techniques de l'hypophysectomie chez les oiseaux. C. R. Soc. Biol. (Paris) 114, 837 (1933)

14. Benoit, J.: Facteurs externes et internes de l'activité sexuelle. II. Etude du mécanisme de la stimulation par la lumière chez le canard domestique. Rôle de l'hypophyse. Bull. Biol. Fr. Belg. 71, 393-437 (1937)

15. Hoffman, W.S.: A rapid method for the determination of glucose in blood and urine. J. Biol. Chem. 120, 51 (1937)

16. Laurell, S., Tibbling, G.: Colorimetric micro-determination of free fatty acids in plasma. Clin. Chim. Acta 16, 57-62 (1967)

17. Laurent, F., Mialhe, P.: Insulin and the glucose-glucagon feedback mechanism in the duck. Diabetologia 12, 23-33 (1976)

18. Leclercq-Meyer, V., Mialhe, P., Malaisse, W. J.: Une méthode de dosage radioimmunologique du glucagon comportant une séparation par le charbon-dextran. Diabetologia 6, 121-129 (1970)

19. Colwell, J.A., Lein, A.: Quantitative relationship between plasma concentration of fatty acids and glucose in normal and diabetic dogs. Diabetes 12, 424-428 (1963)

20. Sokal, J.E., Aydin, A., Kraus, G.: Effect of glucagon on plasma free fatty acids of normal and pancreatectomised dogs. Am. J. Physiol. 211, 1334-1338 (1966)

21. Heald, P.J., McLachlan, P.M., Rookledge, K. A.: The effects of insulin, glucagon and adrenocorticotrophic hormone on the plasma glucose and free fatty acids of the domestic fowl. J. Endocrinol. 33, 83-95 (1965)
22. Grande, F.: Lack of insulin effect on free fatty acids mobilization produced by glucagon in birds. Proc. Soc. Exp. Biol. Med. 130, 711-713 (1969)

23. Grande, F.: Effects of glucagon and insulin on plasma free fatty acids and blood sugar in owls. Proc. Soc. Exp. Biol. Med., 133, 540-543 (1970)

24. Fritz, I. B.: Factors influencing the rates of long chain fatty acid oxidation and synthesis in mammalian species. Physiol. Rev. 41, 52-129 (1969)

25. McElroy, W.T., Sieffert, W.L., Spitzer, J.J.: Relationship of hepatic uptake of free fatty acids to plasma concentration. Proc. Soc. Exp. Biol. Med. 104, 20-23 (1960)

26. Mialhe, A.: Ketone bodies and pancreatic hormones regulation in the duck. Veterinary thesis, Paris (1977)

27. Lefebvre, P.J., Unger, R. H.: Glucagon molecular physiology. Clinical and Therapeutic Implications. Chap. 7. In: Glucagon and Lipid Metabolism, pp. 110, Oxford: Pergamon Press 1972

28. Weinges, K. F.: Der Einfluß von Glucagon und Insulin auf den Stoffwechsel der nicht verersterten Fettsäuren am isolierten Fettgewebe der Ratte in vitro. Klin. Wochenschr. 39, 293-298 (1961)

29. Spirovski, M.Z., Kovacev, M.Z., Spasovska, M., Chernick, S.S.: Effect of ACTH on lipolysis in adipose tissue of normal and adrenalectomised rats in vivo. Am. J. Physiol. 228, 382-385 (1975)

Received: July 15, 1977, and in revised form: September 26, 1977

\section{Dr. R. Gross}

Laboratoire de Physiologie Générale

Université Louis Pasteur

Rue René Descartes

F-67100 Strasbourg

France 